\title{
Transcription Factor Maf
}

National Cancer Institute

\section{Source}

National Cancer Institute. Transcription Factor Maf. NCI Thesaurus. Code C18170.

Transcription factor Maf (373 aa, $\sim 38 \mathrm{kDa}$ ) is encoded by the human MAF gene. This protein is involved in transcriptional regulation. 